\title{
Spatial patterns of larval abundance at hydrothermal vents on seamounts: evidence for recruitment limitation
}

\author{
Anna Metaxas* \\ Department of Oceanography, Dalhousie University, Halifax, Nova Scotia B3H 4R2, Canada
}

\begin{abstract}
Because of their ephemeral nature and patchy distribution, hydrothermal vents on mid-ocean ridges are newly colonized by allochthonous larval sources after catastrophic eruptions, but their hydrothermal benthic invertebrate populations are maintained by local larval supply. In the present study, I examined spatial patterns of larval abundance and associated adult assemblages at hydrothermal vents on 3 seamounts each at the Mariana Arc and Kermadec-Tonga Arc. Because seamounts are topographically distinct features on the ocean floor, colonization processes may differ from those on mid-ocean ridges. On every seamount, the chemosynthetically based macro-epifaunal populations were patchy, spatially constrained and consisting of 1 to 3 numerically dominant taxa that differed among locations within a seamount and among seamounts. Larval abundance was generally greater at 2-7 m above the sea floor than 20-30 m higher, and in 5 of the 6 seamounts, it was lower than has been measured at the same elevations in previous studies on mid-ocean ridges. I examined changes in vertical distribution in experiments using 2 vent species of gastropod larvae hatched from egg capsules collected in situ. For Shinkailepas cf. kaikatensis, larvae were initially more abundant near the water surface, but were more abundant near the bottom $3 \mathrm{~d}$ after hatching, whereas for Shinkailepas n. sp., they remained near the bottom for the duration of the experiment. The observed larval distributions in the field and experiments suggest high larval retention, which can result in high local recruitment, but low colonization of new locations within or among seamounts. In combination with gregarious settlement and potentially limited habitat availability, low colonization is likely to give rise to the paucity of the adult chemosynthetic assemblages observed in the present study, and effect recruitment limitation beyond the local source population of vent species on highly disturbed seamounts that are volcanically active.
\end{abstract}

KEY WORDS: Marine benthic invertebrates . Larval abundance • Larval behaviour . Vertical distribution · Propagule source · Chemosynthetic communities · Volcanic seamounts

\section{INTRODUCTION}

For marine benthic invertebrates with complex life cycles and a dispersive larval phase, larval supply to the benthos affects recruitment, and has been linked to the ultimate spatial distribution of adult populations (Gaines et al. 1985, Minchinton \& Scheibling 1991, Saunders \& Metaxas 2008). For spatially fragmented populations, the exchange of individuals ensures population connectivity and regulates population stability and capacity to expand into new areas (Metaxas \& Saunders 2009). Whether a particular population acts as a source or a sink of dispersing propagules is determined by a combination of life-history characteristics (e.g. mode of larval development, dispersal distance) and the physical environment (e.g. retentive vs. dispersive flows). 
Hydrothermal vents harbour distinct assemblages of benthic invertebrates that are mostly endemic and adapted to the unique conditions of the habitat, such as high temperature, pressure, $\mathrm{H}_{2} \mathrm{~S}$ and metal concentrations, and acidic conditions (Van Dover 2000). Additionally, vents are ephemeral and unstable habitats that may experience catastrophic disturbances, such as repaving and substrate collapse during an eruption, or chronic disturbances through the continuous modification of the speed and chemical composition of the hydrothermal fluid (Haymon et al. 1993, Embley et al. 1999, Butterfield et al. 2004). These disturbances can occur on temporal scales of hours to decades, and spatial scales of metres to $100 \mathrm{~s}$ of $\mathrm{km}$. Benthic populations at vents are established by allochthonous larval sources after catastrophic eruptions (Tunnicliffe et al. 1997, Mullineaux et al. 2010), but are maintained by local larval sources during periods of habitat stability (Metaxas 2004, Adams \& Mullineaux 2008). The extents of larval retention and dispersal are influenced both by larval behaviour and the local and regional hydrodynamics (Marsh et al. 2001, Metaxas 2004, McGillicuddy et al. 2010).

Most studied hydrothermal vents occur along midocean ridges, where the topographic continuity of the axial valley can constrain circulation (Thomson et al. 2003, McGillicuddy et al. 2010) and promote the existence of a homogeneous larval pool across vents separated by $10 \mathrm{~s}$ to $100 \mathrm{~s}$ of $\mathrm{km}$ (Metaxas 2004). In the handful of studies done at vents, mainly on the East Pacific Rise and the Juan de Fuca Ridge, larvae of vent species were more abundant within $5 \mathrm{~m}$ of the bottom than at heights $>20 \mathrm{~m}$ above the bottom (mab) (Mullineaux et al. 1995, 2005, Kim \& Mullineaux 1998, Metaxas 2004) and abundance may (Mullineaux et al. 2005) or may not (Kim \& Mullineaux 1998, Metaxas 2004) decrease with distance from the vents up to $\sim 10 \mathrm{~km}$. These studies suggest that larval dispersal of many vent species likely occurs near the ocean floor, along the mean direction of advective currents (Marsh et al. 2001, Thomson et al. 2003). However, hydrothermal vents also occur on volcanic seamounts, mostly known from the western and southwestern Pacific (e.g. Stoffers et al. 2006, Embley et al. 2007), but less well studied than those on mid-ocean ridges.

On seamounts, it has long been considered that assemblages of benthic invertebrates are characterized by endemicity and high diversity (Clark et al. 2010, Rowden et al. 2010). However, increased sampling effort and genetic studies are now indicating amongseamount variation in the magnitude of population connectivity that depends on physical and geological characteristics of the seamounts and larval characteristics of the organisms (Rowden et al. 2010, Shank 2010). For example, the long-standing hypothesis of endemicity has been associated with the existence of retentive circulation cells over seamounts (such as Taylor caps) that enhance local larval supply and inhibit extensive larval dispersal beyond the seamount (Boehlert \& Genin 1987). However, the presence of such retentive features is not ubiquitous across seamounts, indicating that some other factor is responsible for cases of larval retention, possibly larval behaviour (Clark et al. 2010, Rowden et al. 2010). For chemosynthetically based populations of benthic invertebrates that inhabit volcanic seamounts, dispersal constraints will combine those of vent organisms with those of seamount inhabitants.

In the present study, I examined spatial patterns, and potential mechanisms that give rise to them, in larval assemblages that inhabit hydrothermal vents on 3 seamounts in the Mariana Arc, western Pacific Ocean (NW Rota 1, East Diamante and NW Eifuku) in 2004, and at 3 seamounts on the Kermadec-Tonga Arc, southwestern Pacific (Monowai Volcanic Complex, Volcano 19 and Volcano 1) in 2007. Using the remotely operated vehicle (ROV) 'ROPOS', I quantified larval abundance at different heights above vent fields, and explored the spatial variability in the water column within each seamount, as well as across seamounts within each arc. Using larvae of the vent gastropods Shinkailepas cf. kaikatensis and Shinkailepas n. sp., hatched from egg capsules (collected from vents on East Diamante and NW Eifuku, for each species respectively), I measured changes in larval vertical distribution with age, in experiments conducted on board ship. Additionally, I quantified the abundance of vent adult populations, as the likely local larval source on these seamounts. The present study provides a first estimate of spatial patterns in larval abundance at hydrothermal vents on and among seamounts and relates these patterns to larval behaviour and to the composition of the adult assemblages. In combination, the results provide evidence for limited larval dispersal and consequent recruitment limitation in these habitats.

\section{MATERIALS AND METHODS}

\section{Study sites}

The Mariana Arc is part of the Izu-Bonin-Mariana arc system, an intra-oceanic convergent margin that extends southward $\sim 2500 \mathrm{~km}$ from Japan to south of 

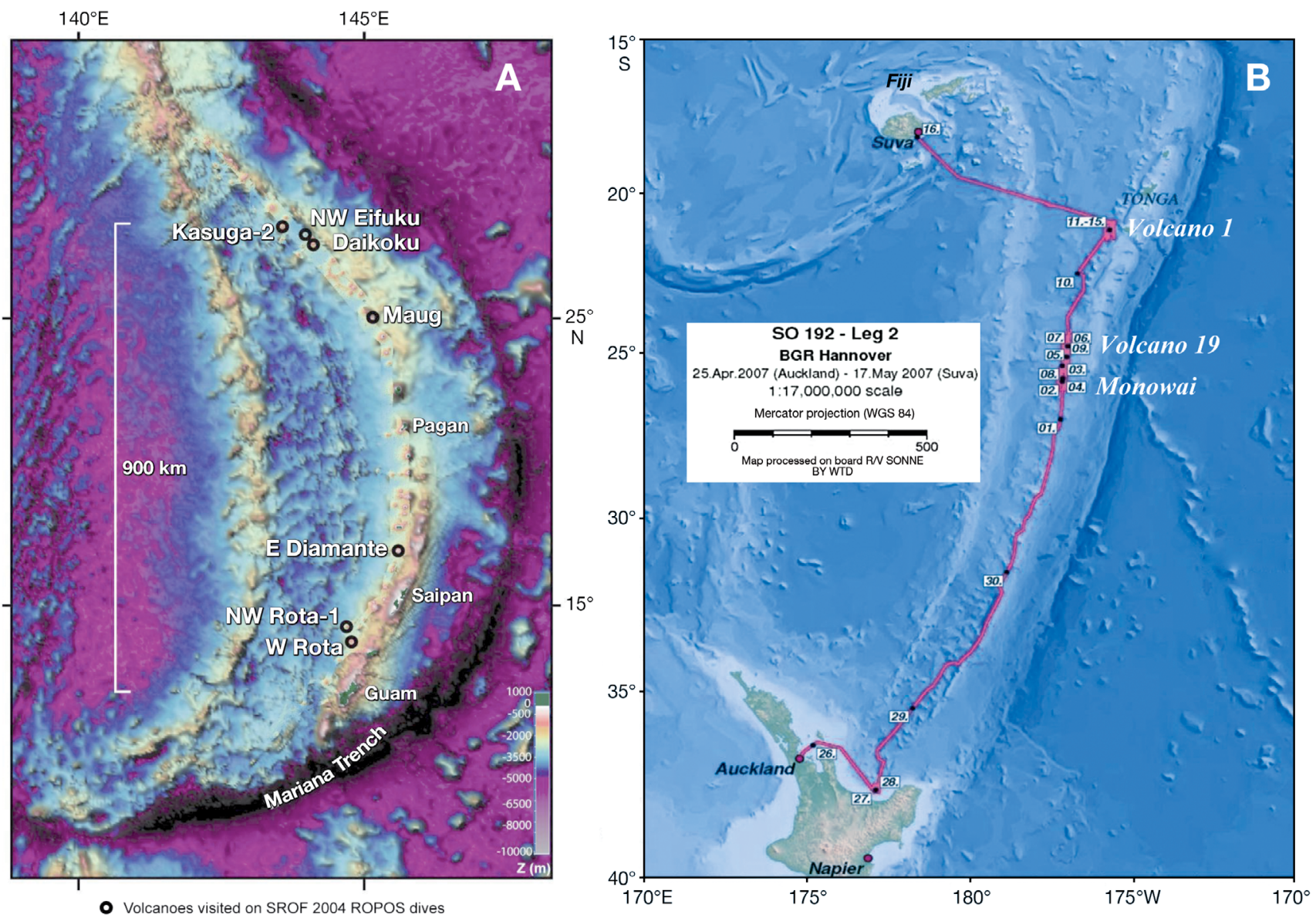

Fig. 1. Locations of sampled volcanic seamounts on (A) the Mariana Arc and (B) the Kermadec-S. Tonga Arc, western and southwestern Pacific, respectively

Guam (Fig. 1A). It is the location of subduction of the Pacific plate below the Philippines plate and, consequently, is an area of submarine hydrothermal activity. Many (>50) hydrothermally active seamounts occur along the Mariana Arc, and, in the present study, I sampled 3: NW Rota 1, East Diamante and NW Eifuku.

NW Rota 1 is an active submarine volcano near the southern end of the arc, and is located $\sim 60 \mathrm{~km}$ north of the island of Rota (Embley et al. 2006; Fig. 1A). The volcano is conical in shape with a diameter of $\sim 16 \mathrm{~km}$, with its base at $\sim 2770 \mathrm{~m}$ and summit at $\sim 517 \mathrm{~m}$ depth (Embley et al. 2006). Weak hydrothermal activity was evident as indicated by scattered areas of diffuse flow across the summit, and an active crater ('Brimstone Pit') was present at $540 \mathrm{~m}$, emitting white clouds laden with liquid sulphur (Embley et al. 2006, 2007).

East Diamante is located $\sim 175 \mathrm{~km}$ north of NW Rota 1 and has a longer geologic history. It is elongate in the east-west direction and has a partly degraded caldera with a cluster of young cones in the centre (Embley et al. 2007), where hydrothermal activity was detected. At the easternmost portion of the central cone was a system of black smokers ('Black Forest') at the shallowest depth recorded to date $(345 \mathrm{~m})$ with a temperature of $242^{\circ} \mathrm{C}$ (Embley et al. 2007). Areas of diffuse flow occurred throughout the central cone complex at 300 to $450 \mathrm{~m}$ depths (Sites 'Barnacle Beach', 'Intense Diffuse', 'Mat City', 'Limpets' and 'Mn-Fe crust').

NW Eifuku is a relatively small, conical volcano in the Northern Seamount Province, located $\sim 500 \mathrm{~km}$ north-northwest of East Diamante. It is the deepest sampled volcano with its summit at $1563 \mathrm{~m}$ depth. A notable feature of this volcano was the occurrence of white smokers at $\sim 1600 \mathrm{~m}$ that emit $\mathrm{CO}_{2}$-rich hydrothermal fluid at $102^{\circ} \mathrm{C}$ (Site 'Champagne') (Lupton et al. 2006, Embley et al. 2007). Additionally, lowtemperature diffuse venting occurred in a small area at $1570 \mathrm{~m}$ depth (Tunnicliffe et al. 2009).

The Kermadec-S. Tonga Arc is a $2500 \mathrm{~km}$ chain of submarine volcanoes located off the northern coast of New Zealand and extending to the southern coast 
of Fiji (Fig. 1B). In the north, the Tonga Arc extends from $16^{\circ} \mathrm{S}$ to $27^{\circ} \mathrm{S}$, and, in the south, the Kermadec Arc extends from $27^{\circ} \mathrm{S}$ to $38^{\circ} \mathrm{S}$. Three volcanoes were sampled along the Kermadec-S. Tonga Arc: Monowai Volcanic Complex, Volcano 19 and Volcano 1.

Monowai Volcanic Complex is a $10 \mathrm{~km}$-wide active submarine volcano with a caldera complex. It is located at the transition zone between the southern end of the Tonga Arc and the northern end of the Kermadec Arc. It consists of a symmetric cone which shoals to $98 \mathrm{~m}$ depth, and a sunken caldera northnortheast of the summit (Schwarz-Schampera et al. 2007). Low-temperature diffuse hydrothermal venting of weakly acidic vent fluids with high $\mathrm{H}_{2} \mathrm{~S}$ content occurred on the western side of Monowai caldera at $\sim 1150 \mathrm{~m}$ depth (Site 'Mussel Ridge'). The substrate was muddy with slabs of sulphur-cemented ash, rich in hydrocarbons and massive anhydrite (Schwarz-Schampera et al. 2007).

Volcano 19 is a large volcano $(14 \times 12 \mathrm{~km})$ located at the southernmost part of the Tonga Arc, $\sim 90 \mathrm{~km}$ north of Monowai, and it rises from 1400 to $\sim 385 \mathrm{~m}$ depth (Schwarz-Schampera et al. 2007). The summit includes an old collapsed caldera, an infilling cone and a younger caldera on the western side. There were 2 areas of hydrothermal vent fields on Volcano 19. One was an area of low-temperature venting located on the southern wall of the western caldera, and the other included high-temperature vents $(\sim 250$ to $270^{\circ} \mathrm{C}$ ) and was located near the summit of the central cone.
Volcano 1 is also a large volcano with a basal diameter of $28 \mathrm{~km}, \sim 360 \mathrm{~km}$ north of Volcano 19, and rising from $1800 \mathrm{~m}$ to a summit at $65 \mathrm{~m}$ depth. The floor of its collapsed central caldera is at 400 to $500 \mathrm{~m}$ depth. Low-temperature hydrothermal activity was located on the slopes of western and southwestern post-caldera scoria cones, at $\sim 100 \mathrm{~m}$ depth (Sites 'Super Cool', 'Barracuda' and 'Bubbles') (SchwarzSchampera et al. 2007).

\section{Field sampling}

At each volcano, plankton samples were collected at each of 2 depths ( $<10$ or 20-35 mab) in the water column above the hydrothermal vent fields with paired $(n=2)$ nets $(63 \mu \mathrm{m}$ mesh) mounted on the bumper bar on the top front side of the ROV 'ROPOS' (Table 1). The nets remained closed until the beginning and were cinched at the end of each tow to prevent inadvertent collection or loss of samples. An additional pair of samples was collected over the erupting Brimstone Pit at NW Rota 1, which were not, however, included in the analyses (although data are shown) because their height relative to the seafloor could not be determined. On board ship, the contents of the nets were gently rinsed down into the cod end and the sample was preserved in $95 \%$ ethanol; larvae and holoplankton were enumerated later in the entire sample under a stereomicroscope. Sample volumes of the net samples were calculated as $\pi r^{2} u t$, where $r$ is the radius of the net mouth opening

Table 1. Locations and characteristics of plankton tows done with ROV 'ROPOS' at different heights in the water column above hydrothermal vents on volcanic seamounts in the western Pacific

\begin{tabular}{|c|c|c|c|c|c|c|}
\hline Arc & Volcano & $\begin{array}{c}\text { Date } \\
\text { (dd/mm/yy) }\end{array}$ & Dive & Location & $\begin{array}{c}\text { Height above } \\
\text { bottom }(\mathrm{m})\end{array}$ & $\begin{array}{l}\text { Volume } \\
\left(\mathrm{m}^{3}\right)\end{array}$ \\
\hline \multirow[t]{7}{*}{ Mariana } & \multirow[t]{3}{*}{ NW Rota 1} & $29-30 / 3 / 04$ & $\mathrm{R} 783$ & Shimmering Shrimp to Fault Shrimp & $3-5$ & 51.4 \\
\hline & & $30-31 / 3 / 04$ & R784 & Summit & 30 & 236.8 \\
\hline & & $1-2 / 4 / 04$ & R786 & Brimstone Pit & $25-27$ & 27.3 \\
\hline & \multirow[t]{2}{*}{ East Diamante } & $3-4 / 4 / 04$ & R787 & Black Forest & 35 & 29.7 \\
\hline & & $4-5 / 4 / 04$ & $\mathrm{R} 788$ & Black Forest & $2-3$ & 36.1 \\
\hline & \multirow[t]{2}{*}{ NW Eifuku } & 9/4/04 & R791 & Mussel Cliff / Mussel Mound & $3-6$ & 32.1 \\
\hline & & $11-12 / 4 / 04$ & R793 & Mussel Mound / Champagne & 30 & 165.3 \\
\hline \multirow[t]{7}{*}{ Kermadec-S. Tonga } & \multirow[t]{2}{*}{ Monowai } & $3 / 5 / 07$ & R1043 & Mussel Ridge & $3-7$ & 26.6 \\
\hline & & $4 / 5 / 07$ & R1044 & Mussel Ridge & 25 & 24.9 \\
\hline & \multirow[t]{2}{*}{ Volcano 19} & $5 / 5 / 07$ & R1046 & Western Caldera - Central Complex & $20-25$ & 88.3 \\
\hline & & $6 / 5 / 07$ & R1047 & Marker 40 / Central Complex & $3-9$ & 65.8 \\
\hline & \multirow[t]{3}{*}{ Volcano 1} & $11 / 5 / 07$ & R1050 & Middle crater in Chain of Craters & $5-7$ & 80.3 \\
\hline & & $12 / 5 / 07$ & R1051 & Middle crater in Chain of Craters & 25 & 72.2 \\
\hline & & $14 / 5 / 07$ & R1053 & Barracuda & $4-5$ & 26.5 \\
\hline
\end{tabular}


$(=15 \mathrm{~cm}), u$ is the speed of the ROV during the tow (ranging from 0.5 to $1 \mathrm{knot}$ ), and $t$ is the total time of the tow (ranging from 30 to $295 \mathrm{~min}$ ). Variation in sample volumes resulted from variation in $t$. All plankton were identified to the lowest taxonomic level possible on the basis of morphology. For each arc, I examined differences in the abundance of each taxon among volcanoes and between heights above the bottom using 2-way ANOVA (both factors fixed) and Student-Newman-Keuls (SNK) tests for post hoc comparisons.

On each volcano, the adult assemblages were described from imagery obtained using a colour video camera (Sony DXC-990 3-CCD, broadcast quality NTSC, 16× zoom) and from images with a Sony Cybershot DSC-F707 camera mounted on the ROV 'ROPOS'. To calculate macrofaunal abundance, I used as many non-overlapping frame grabs extracted from the video as were available; on these images, 2 lasers, spaced $10 \mathrm{~cm}$ apart and visible on the video, were used for scale reference. The higher-resolution images from the Sony Cybershot camera were used in instances where taxon identification was not possible and a still image was available.

\section{Changes in larval distribution with age}

Rocks with egg capsules, each containing 80 to 100 embryos, were collected from East Diamante (Central Cone) and NW Eifuku (Champagne) with ROV 'ROPOS', placed in glass beakers in ambient seawater collected in situ diluted by $1 / 3$ with $63-\mu \mathrm{m}$ filtered seawater collected from the sea surface, and kept in a $5^{\circ} \mathrm{C}, 1 \mathrm{~atm}$ walk-in environmental chamber on board ship. Within 9 to $14 \mathrm{~h}$, gastropod veligers hatched out of the egg cases and were swimming in the beakers. Larvae were reared in the beakers where they hatched, and the water was changed every day and lightly aerated intermittently.

Using these veligers, I conducted 3 opportunistic experiments on board ship to record changes in larval vertical distribution (as a proxy for larval behaviour) with age in 2 species of limpets, Shinkailepas cf. kaikatensis from East Diamante and Shinkailepas n. sp. from NW Eifuku.

Expt 1: I used a single batch of veligers of Shinkailepas cf. kaikatensis hatched on 9 April 2004 from egg capsules on rocks collected on Dive R788 from the Central Cone of East Diamante. Approximately 150 larvae were placed in a glass beaker which provided a $5.5 \mathrm{~cm}$ deep water column, and the number of larvae in each of 6 depth categories (on the bottom, 0-2 cm, 2-3 cm, 3-4 cm, 4-5 cm, and at the surface) was recorded every $24 \mathrm{~h}$ for 4 consecutive days.

Expt 2: To obtain a longer time series, I used multiple batches of veligers of Shinkailepas cf. kaikatensis, at ages 1 to $8 \mathrm{~d}$ old. Specifically, veligers hatched on 7 April 2004 were used on 12 April ( 5 d old), 13 April (6 d old), 14 April (7 d old), and 15 April (8 d old); veligers hatched on 8 April were used on 14 April (6 d old); veligers hatched on 11 April were used on 13 April ( $3 \mathrm{~d}$ old) and 14 April (4 d old); and veligers hatched on 13 April were used on 14 April ( $1 \mathrm{~d}$ old $)$ and 15 April $(2 \mathrm{~d}$ old). On the day of observation, 20 to 50 veligers were transferred from the culture jar to each of 1 to 6 Petri dishes (Day 6: $\mathrm{n}=$ 6; Days 1, 2, 3 and 5: $\mathrm{n}=5$; Day 8: $\mathrm{n}=2$; Days 4 and 7: $\mathrm{n}=1$ ), which provided a 3 -cm deep water column. I recorded the number of larvae in the top and bottom 1.5-cm interval (surface and bottom, respectively).

Expt 3: Using the same types of containers ( $\mathrm{n}=5$ on each day) and experimental design as in Expt 2, I measured changes in the vertical distribution of a single batch of Shinkailepas n. sp. hatched on 11 April 2004 from egg capsules on rocks collected on Dive R792 from 'Champagne', every $24 \mathrm{~h}$ for $4 \mathrm{~d}$. No mortality was observed during any of the experiments.

For each experiment, I examined the independence of position (Expt 1: 6 categories; Expts 2 and 3: 2 categories) and age (Expts 1 and 3: 4 categories [Day 1 to Day 4]; Expt 2: 8 categories [Day 1 to Day 8]) using 2-way contingency tables and analysis of frequencies by log-linear models. In this analysis, treatments are independent when a log-linear model fits the data well, and the values of the G-statistic are low and therefore not significant (Fienberg 1970, Sokal \& Rohlf 1981). For the factor position, the categories (depths) were selected to provide an even distribution throughout the container, and to account for larvae on the bottom and at the surface. For the analyses, frequencies of larvae in each category were pooled across replicate containers, because position was independent of replicate (Sokal \& Rohlf 1981). All analyses were done using the software PASW (SPSS) 17.0. These experiments did not attempt to reproduce larval behaviour in a setting that simulated the natural environment, which is logistically unfeasible on board ship; their design was limited by the available resources. Consequently, they were designed to evaluate whether larvae exhibit firstorder swimming behaviours that can be attributed to larval position in the water column, and thus that could be related to depth selection in the absence of any cues. 


\section{RESULTS}

\section{Spatial patterns of mero- and holoplankton}

The composition and abundance of meroplanktonic larvae of benthic epifaunal invertebrates varied both among volcanoes within an arc, as well as between heights above the hydrothermal vent fields. While larvae could not be assigned to vent species (except for the gastropods Shinkailepas cf. kaikatensis and Shinkailepas n. sp., which were reared on board ship), by far the majority of macrofaunal biomass on these seamounts belonged to vent fauna. Where non-vent epifauna were observed in significant abundance, they belonged to Cnidaria or Echinodermata, both of which have identifiable larval types. Consequently, I assume that most larvae collected in the plankton nets belonged to vent macroinvertebrates.

On the Mariana Arc, plankton tows at NW Eifuku included the largest number of taxa. For all taxa, there were no significant interactive effects of Volcano and Height on abundance. Gastropod larvae were present at all 3 volcanoes; they were less abundant at NW Rota 1 than East Diamante and NW Eifuku, although the difference was marginally nonsignificant $\left(F_{2,6}=4.83, \mathrm{p}=0.056\right)$ (Fig. 2$)$. They were the only meroplanktonic taxon collected over the Brimstone Pit at NW Rota 1. Bivalves were present only at NW Rota 1 and NW Eifuku (in similar abundance; $F_{1,3}=0.036, \mathrm{p}=0.858$ ), decapods at East Diamante and NW Eifuku (in similar abundance; $F_{1,2}=$ $0.124, p=0.758$ ), and a single barnacle zoea was collected $30 \mathrm{~m}$ above the vent field on NW Rota 1 (Fig. 2). Within volcanoes, larval gastropods were significantly more abundant near the seafloor $(<6 \mathrm{~m})$ than 30-35 m higher $\left(F_{1,6}=13.19, \mathrm{p}=0.011\right)$. Decapods and polychaetes were only found at 3-6 mab, and bivalves at both NW Rota 1 and NW Eifuku were more abundant closer to the seafloor than at 30$35 \mathrm{mab}$, although the difference was not statistically significant $\left(F_{1,4}=3.10, \mathrm{p}=0.153\right)$ (Fig. 2).

Meroplanktonic larvae showed similar variability between heights above the bottom and among volcanoes on the Kermadec-S. Tonga Arc as in on the Mariana Arc (Fig. 3). The greatest abundances of taxa were recorded on Volcano 1. While most taxa were present on all 3 volcanoes, polychaetes were not collected on Volcano 19. For gastropods, bivalves and polychaetes, there was a significant Volcano $\times$ Height interaction on abundance $\left(F_{2,6}=7.59, \mathrm{p}=0.023 ; F_{2,6}=\right.$ $10.4, \mathrm{p}=0.011 ; F_{1,4}=38.3, \mathrm{p}=0.003$; for each taxon, respectively). Abundance of gastropods at both heights was greater on Volcano 1 than on the other 2 volcanoes (SNK tests, $\mathrm{p}<0.05$ ), and that of bivalves and polychaetes near the seafloor was greater at Monowai (SNK tests, $\mathrm{p}<0.05$ ). Gastropods were significantly more abundant near the seafloor than at $>20 \mathrm{~m}$ above the vents at Volcano 1 (SNK test, $\mathrm{p}<$ 0.05), as well as on Monowai although this was a marginally not-significant difference (SNK test, $0.10>\mathrm{p}>$ 0.05). Bivalves and polychaetes were more abundant near the seafloor than at 25 mab, but only on Monowai (SNK test, $\mathrm{p}<0.05$ ). Abundance of decapods did not vary among volcanoes $\left(F_{2,6}=2.24, \mathrm{p}=\right.$ $0.188)$ or between heights $\left(F_{1,6}=0.441, \mathrm{p}=0.531\right)$, and there was no significant interaction between the 2 factors $\left(F_{2,6}=0.113, \mathrm{p}=0.895\right)$.
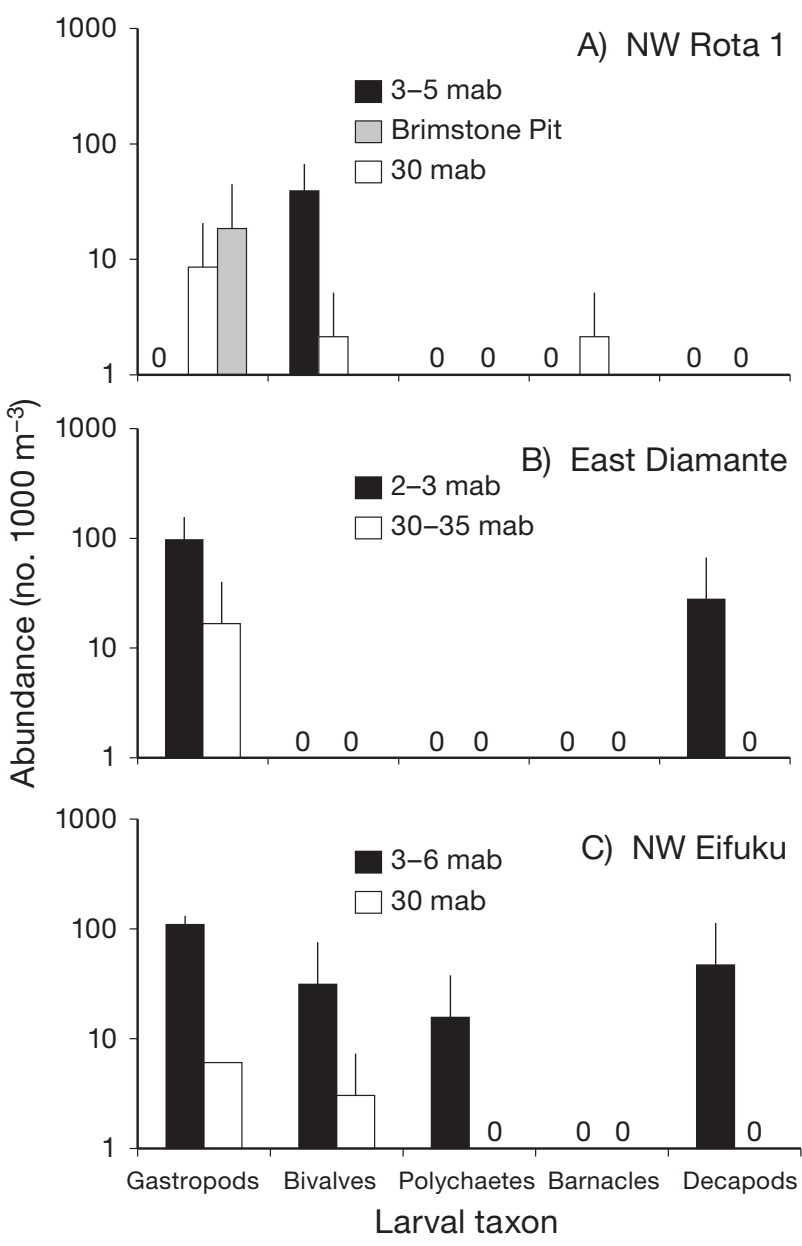

Fig. 2. Abundance (mean $\pm \mathrm{SD}, \mathrm{n}=2$ ) of meroplankton sampled near the bottom and at 30-35 $\mathrm{m}$ above vent fields on (A) NW Rota 1, (B) East Diamante and (C) NW Eifuku on the Mariana Arc in April-May 2004. Gastropods were the only taxon present above the Brimstone Pit on NW Rota; their abundance was not included in the analysis because of the particularity of the habitat and because the location relative to the bottom could not be assessed. mab: $\mathrm{m}$ above bottom 


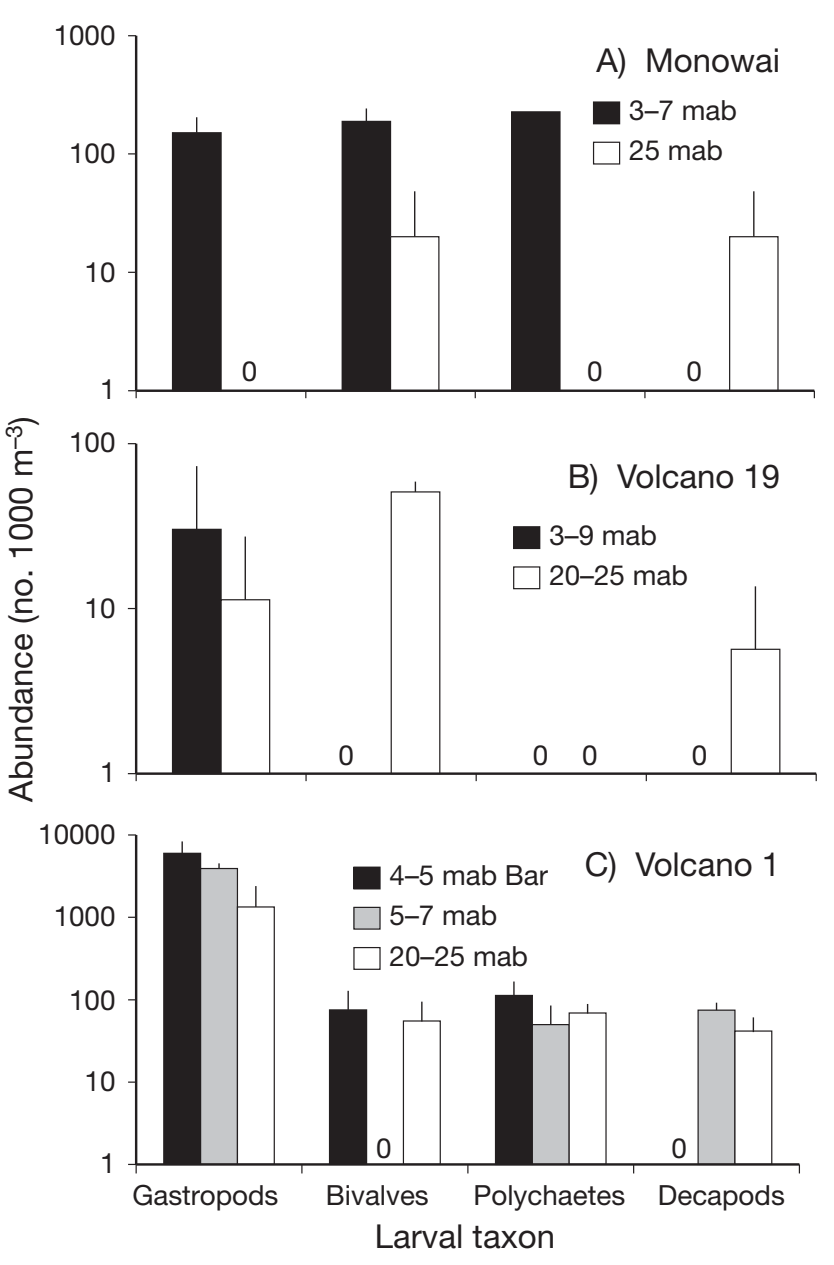

Fig. 3. Abundance (mean $\pm \mathrm{SD}, \mathrm{n}=2$ ) of meroplankton sampled near the bottom and at 20-25 m above vent fields on (A) the Monowai Volcanic Complex, (B) Volcano 19 and (C) Volcano 1 on the Kermadec-S. Tonga Arc in May 2007. On Volcano 1, near-bottom samples were collected at 2 locations (Barracuda: 4-5 mab Bar, and the Middle Crater: 5-7 mab), shown separately but averaged for the analyses (see Table 1 for details). Note the different $y$-axis scales. mab: $m$ above bottom

The most abundant holoplankton were vent and pelagic copepods and nauplii, and foraminiferans. The vent copepods belonged to different families in the Order Siphonostomatoida, most of which are exclusively found at hydrothermal vents (Desbruyères et al. 2006). The pelagic copepods included both calanoids (such as the genera Centropages, Paracalanus, Pseudocalanus and Clausocalanus) and cyclopoids. On the Mariana Arc, there were no significant interactive effects of Volcano and Height on the abundance of any holoplanktonic taxon (in all cases, $F_{2,6}<1.5, \mathrm{p}>0.30$ ). Only foraminiferan abundance varied significantly among volcanoes $\left(F_{2,6}=14.7, \mathrm{p}=\right.$ 0.005), and they were less abundant at NW Rota 1
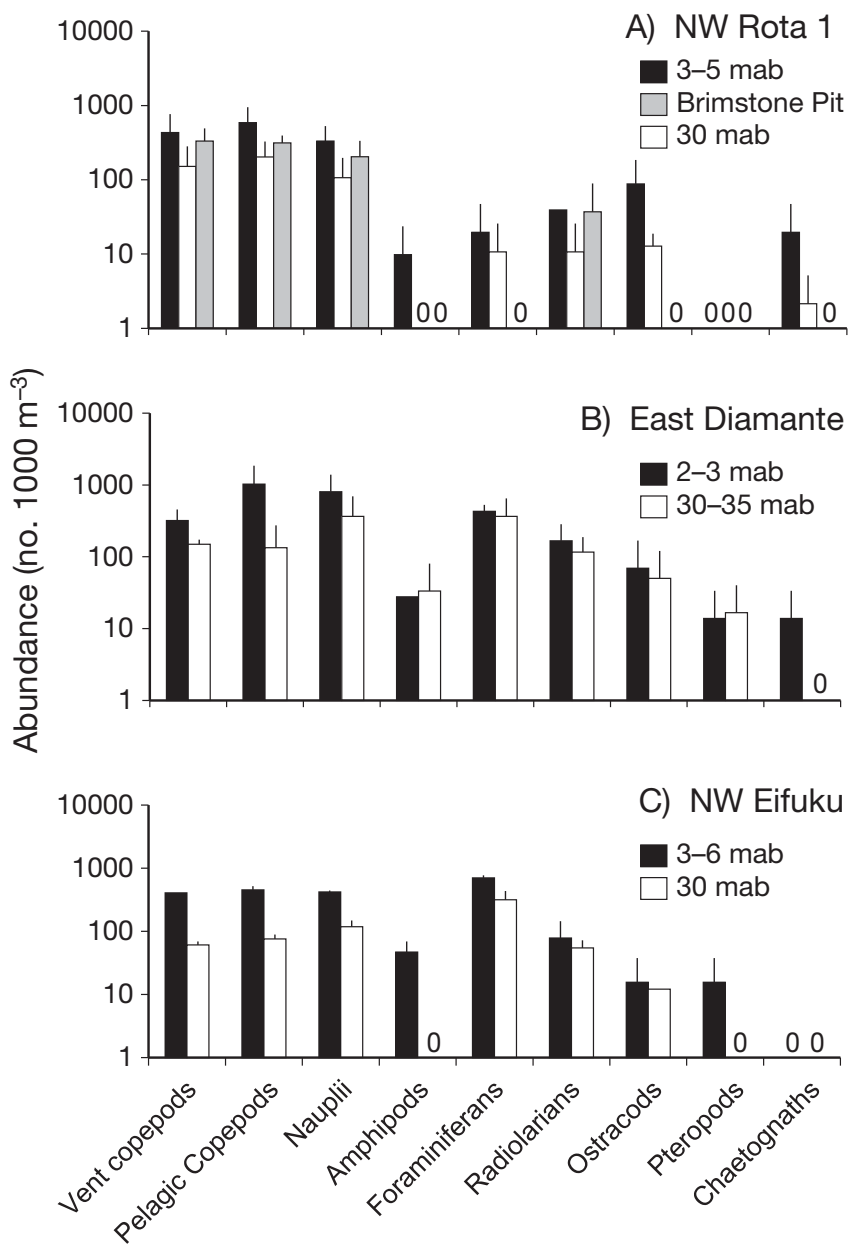

Fig. 4. Abundance (mean $\pm \mathrm{SD}, \mathrm{n}=2$ ) of holoplankton sampled near the bottom and at 30-35 $\mathrm{m}$ above vent fields on (A) NW Rota 1, (B) East Diamante and (C) NW Eifuku on the Mariana Arc in April-May 2004. Vent and pelagic copepods and nauplii were the only taxa present above the Brimstone Pit on NW Rota; their abundance was not included in the analysis because of the particularity of the habitat and because the location relative to the bottom could not be assessed. mab: $m$ above bottom

than East Diamante and NW Eifuku (Fig. 4). Vent and pelagic copepods and nauplii were also found in significant abundances above the Brimstone Pit at NW Rota 1. The abundances of vent $\left(F_{1,6}=8.59, \mathrm{p}=\right.$ $0.026)$ and pelagic copepods $\left(F_{1,6}=6.46, \mathrm{p}=0.044\right)$ were significantly greater near the seafloor than at 30-35 mab (Fig. 4). Abundance of all other taxa also was greater at 2-6 than 30-35 mab, although not statistically significantly (in all cases, $F_{1,6}<3.7, \mathrm{p}>0.10$ ).

On the Kermadec-S. Tonga Arc, there was less variability in the abundance of holoplankton among volcanoes and between heights above the vent field (Fig. 5) than on the Mariana Arc. Pelagic copepods were more abundant at Volcano 1 than at Monowai 


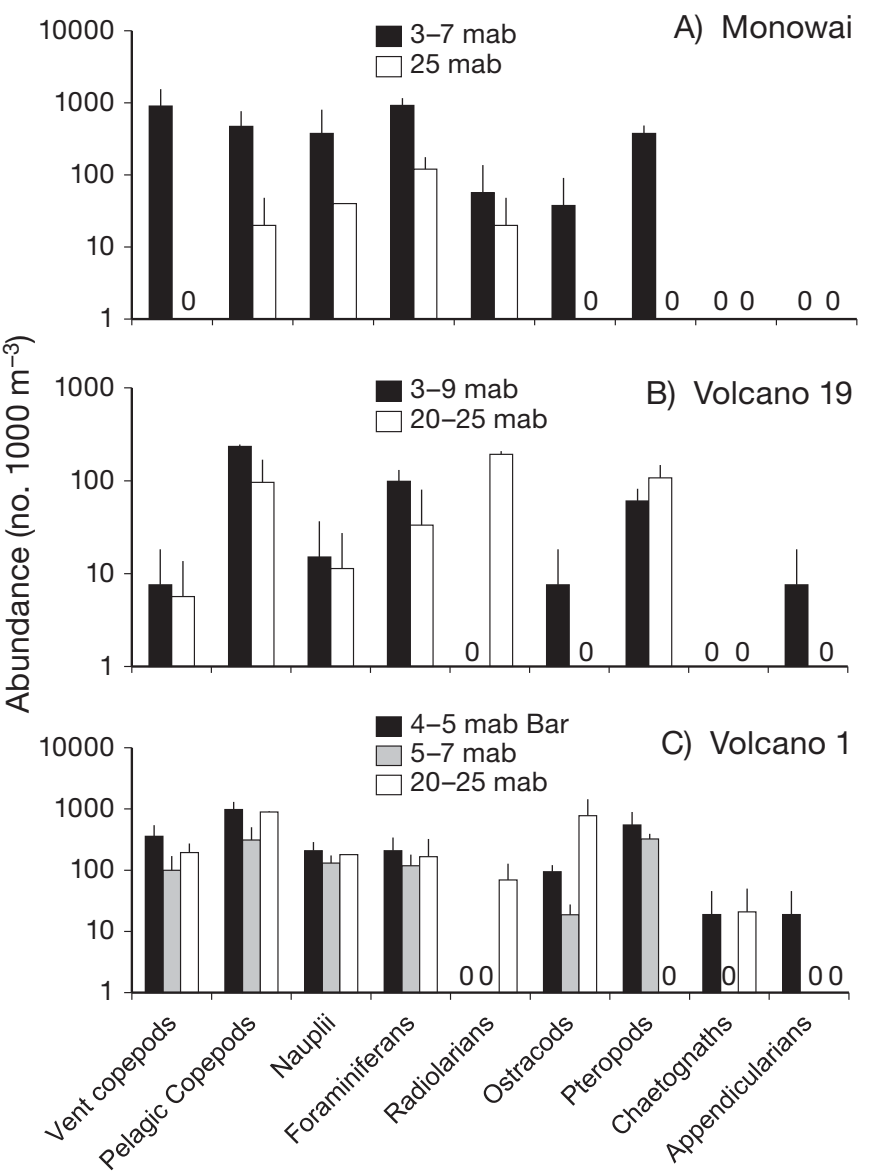

Fig. 5. Abundance (mean $\pm \mathrm{SD}, \mathrm{n}=2$ ) of holoplankton sampled near the bottom and at 20-25 m above vent fields on (A) the Monowai Volcanic Complex, (B) Volcano 19 and (C) Volcano 1 (see Fig. 3 for further explanation) on the Kermadec-S. Tonga Arc in May 2007. mab: $m$ above bottom. Note the different $y$-axis scales and Volcano $19\left(F_{2,6}=8.14, \mathrm{p}=0.02 ;\right.$ SNK tests, $\mathrm{p}<$ 0.05). Overall, abundance of vent copepods and nauplii, ostracods and pteropods was lower at Volcano 19, whereas that of radiolarians was greater at Monowai than on the other 2 volcanoes sampled in this arc; however, these differences were statistically non-significant (in all cases, $F_{2,6}<3.8, \mathrm{p}>0.09$ ). Vent copepods, nauplii and radiolarians tended to be more abundant immediately above the vents than at 20-25 m height, but, again, the differences were nonsignificant (in all cases, $F_{1,6}<4.0, \mathrm{p}>0.094$ ). For foraminiferans, there was a significant interaction between Volcano and Height $\left(F_{2,6}=16.2, \mathrm{p}=0.004\right)$. This group was more abundant on Monowai than on the other volcanoes, and near the seafloor than at 25 mab on Monowai (SNK tests, $\mathrm{p}<0.05$ ). No other interactions were significant (in all cases, $F_{2,6}<3.5$, $\mathrm{p}>$ 0.098).

\section{Changes in larval distribution with age}

I was able to maintain larval cultures of Shinkailepas cf. kaikatensis hatched from egg capsules collected at the Central Cone on East Diamante for $8 \mathrm{~d}$ (Fig. 6), and cultures of Shinkailepas n. sp. from 'Champagne' on NW Eifuku for $4 \mathrm{~d}$ (from date of collection until the end of the cruise). Although the larvae were not fed during this period, they appeared healthy and no mortality occurred in the cultures.

The vertical distribution of larvae in the experimental containers differed between the 2 species. While
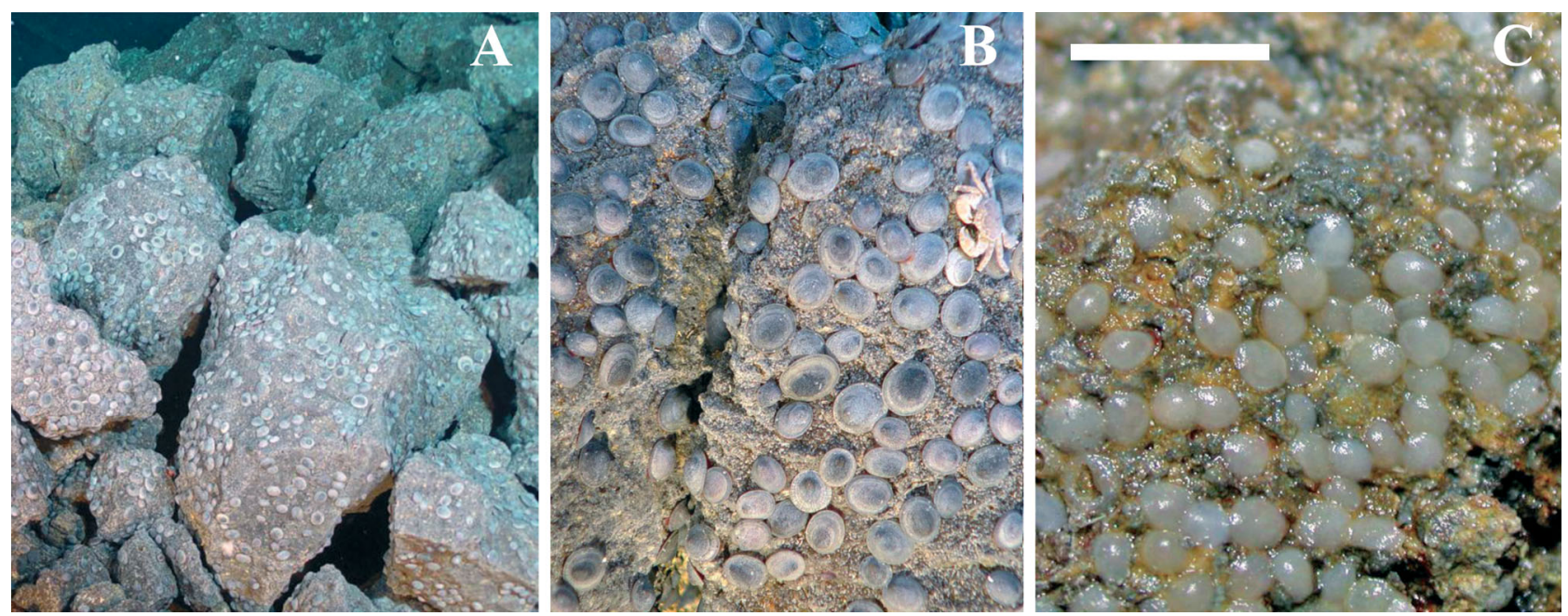

Fig. 6. Shinkailepas cf. kaikatensis. (A) Population of the limpet in diffuse flow on the Central Cone, at East Diamante. (B) Closeup of limpets, with egg capsules visible as white dots covering the substratum between limpets. (C) Close-up of individual egg capsules. Scale bar $=5 \mathrm{~mm}$ 


\section{Percentage of larvae}

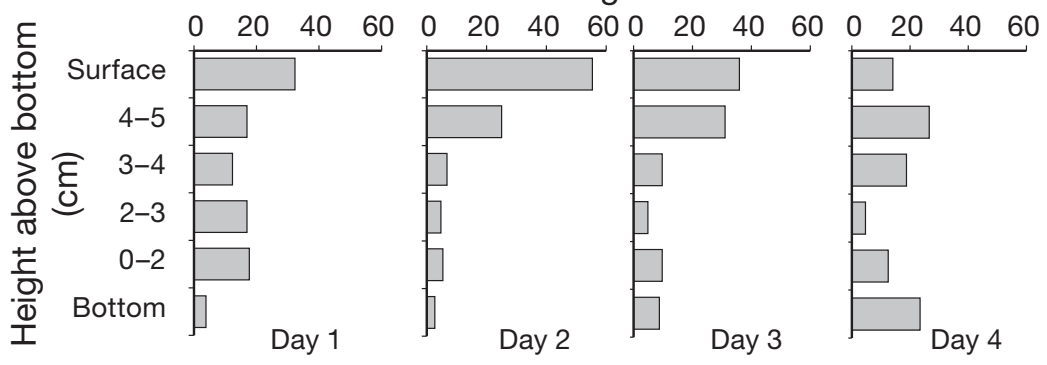

Fig. 7. Shinkailepas cf. kaikatensis. Expt 1. Change in larval vertical distribution over a period of $4 \mathrm{~d}$. Larvae of a single cohort, hatched from egg capsules collected from the Central Cone at East Diamante more evenly distributed throughout the water column on Day 4. Consequently, larval position was dependent on age $\left(\mathrm{X}^{2}{ }_{15}=82.9, \mathrm{p}<0.001\right)$. Similarly, in Expt 2, the proportion of larvae near the surface decreased from $80 \%$ on Day 1 to $20 \%$ on Day 8 , and larval position was again dependent on age $\left(\mathrm{X}_{5}{ }_{5}=99.6, \mathrm{p}<0.001\right)$. In contrast, for Shinkailepas n. sp., larval position was independent of age in Expt $3\left(\mathrm{X}_{3}{ }_{3}=6.05, \mathrm{p}=0.109\right)$ (Fig. 8). larvae of Shinkailepas cf. kaikatensis were found near the surface for the first $3 \mathrm{~d}$ of development, and then nearer the bottom of the containers (Fig. 7), those of Shinkailepas n. sp. were found on the bottom (and not swimming in the water column) throughout the experiment (Fig. 8). Specifically, in Expt 1, larvae of $S$. cf. kaikatensis were more abundant near the surface of the containers in the first $3 d$, but then became

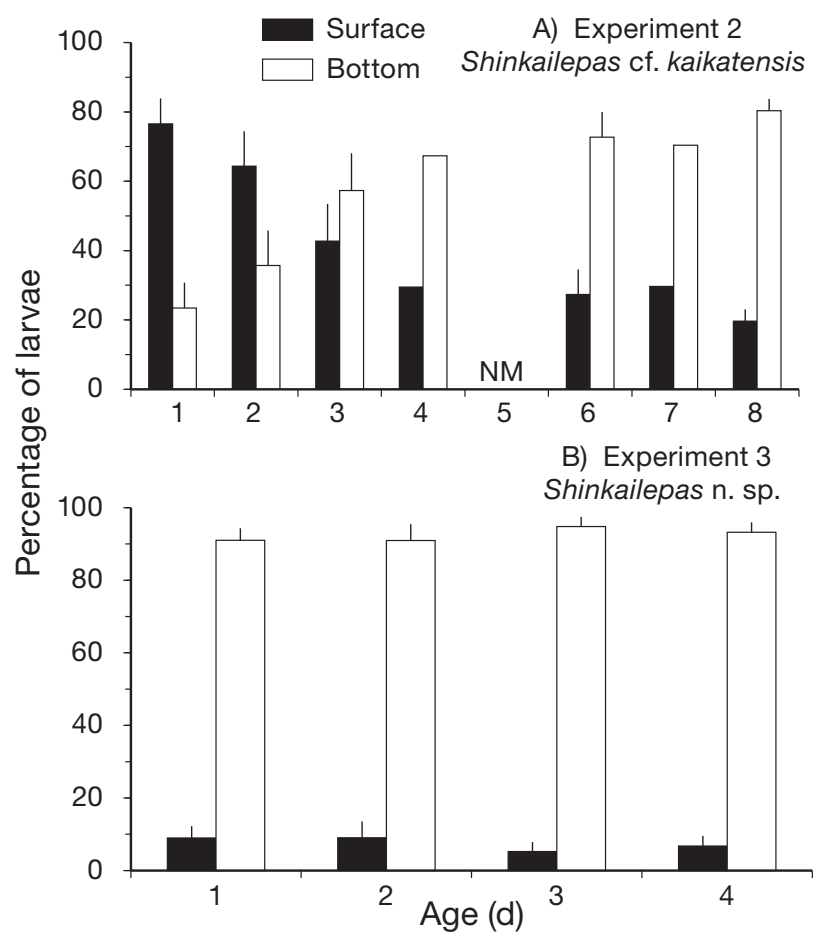

Fig. 8. Shinkailepas cf. kaikatensis and Shinkailepas n. sp. Change in larval vertical distribution of (A) S. cf. kaikatensis (Expt 2) and (B) Shinkailepas n. sp. (Expt 3) over a period of 8 and 4 d, respectively. Larvae of $S$. cf. kaikatensis from 4 cohorts (see 'Materials and methods'), hatched daily over a period of $7 \mathrm{~d}$ from egg capsules collected from the Central Cone at East Diamante. Larvae of Shinkailepas n. sp. were from a single cohort, hatched from egg capsules collected from the 'Champagne' site at NW Eifuku. NM: not measured

\section{Composition of potential local 'source' populations}

The adult assemblages of epifaunal macroinvertebrates were distinct among volcanoes within each arc, likely reflecting habitat instability and colonization history. Also, distinct but sparse patches of 1 to 3 taxa occurred within each volcano, which were in the order of $10 \mathrm{~s}$ to $100 \mathrm{~s}$ of $\mathrm{m}^{2}$ in areal coverage. On the Mariana Arc, at NW Rota 1, vent assemblages included patchy distributions of 2 species of alvinocarid shrimp (Opaepele loihi and a less abundant Alvinocaris n. sp.) on a series of outcrops along the ridge east of the erupting Brimstone Pit (Table 2). Localized high abundances of the gastropod Shinkailepas $\mathrm{n}$. sp. were recorded at 1 location (Table 2). The vent sites where these fauna were found were separated by 60 to $100 \mathrm{~m}$ from one another.

On East Diamante, distinct patches of different numerically dominant taxa occurred at different locations on the volcano. The central cone included locations of extremely high abundances of the limpet Shinkailepas cf. kaikatensis and the crab Austinograea yunohana (Table 2). At $700 \mathrm{~m}$ to the northeast, small populations of the snail Alvinoconcha n. sp. were found along the bases of the smokers at 'Black Forest' (Table 2). Downslope from this site and $\sim 250 \mathrm{~m}$ to the northeast, almost $100 \%$ cover of the barnacle Neoverruca n. sp. occurred at 'Barnacle Beach'. Other collected taxa included a polynoid polychaete, and a provannid and a trochid snail (V. Tunnicliffe pers. comm.).

At NW Eifuku, the vent mussel Bathymodiolus brevior formed an extensive bed $\left(\sim 10000 \mathrm{~m}^{2}\right)$ of almost uniform abundance and size distribution ( approx. 10 to $15 \mathrm{~cm}$ shell length [SL]) near the summit (Table 2) (see also Tunnicliffe et al. 2009). Smaller mussels $(<3 \mathrm{~cm} \mathrm{SL})$ were observed only at the edge of the bed and in low abundance $\left(<10\right.$ mussels $\left.\mathrm{m}^{-2}\right)$. Near the periphery, the continuous bed was replaced by 
Table 2. Abundance (density or percentage cover) of macrofaunal assemblages at hydrothermal vents on 3 volcanic seamounts on the Mariana Arc, measured from frame grabs obtained with a video camera attached to the ROV 'ROPOS' in April-May 2004. Data are mean \pm SD

\begin{tabular}{|c|c|c|c|c|c|}
\hline Seamount & Species & Dive & Location (depth, m) & $\begin{array}{l}\text { Density, ind. } \mathrm{m}^{-2} \\
\text { (sample size) }\end{array}$ & $\begin{array}{l}\text { Percentage cover, } \\
\% \text { (sample size) }\end{array}$ \\
\hline \multirow[t]{6}{*}{ NW Rota 1} & Alvinocaris n. sp. & R782 & Shimmering Vent, Scarp Top (515-565) & $24 \pm 13(4)$ & \\
\hline & & $\mathrm{R} 783$ & Fault Shrimp, Scarp Top, Hi Flow (515-565) & $12 \pm 10(3)$ & \\
\hline & Opaepele loihi & R782 & Shimmering Vent, Scarp Top (515-565) & $231 \pm 219(6)$ & \\
\hline & & $\mathrm{R} 783$ & Fault Shrimp, Scarp Top, Hi Flow (515-565) & $494 \pm 418(6)$ & \\
\hline & Shinkailepas n. sp. & R782 & Gastros (530) & $167 \pm 37(2)$ & \\
\hline & & R783 & Gastros (530) & $45 \pm 8(2)$ & \\
\hline \multirow{6}{*}{$\begin{array}{l}\text { East } \\
\text { Diamante }\end{array}$} & Neoverruca n. sp. & $\mathrm{R} 787$ & Barnacle Beach (460) & & $100 \pm 0.0(2)$ \\
\hline & & R788 & Barnacle Beach (460) & & $86.7(1)$ \\
\hline & Austinograea yunohana & R788 & Boulder (265) & $43 \pm 21(2)$ & \\
\hline & Shinkailepas cf. kaikatensis ${ }^{\mathrm{a}}$ & $\mathrm{R} 787$ & Boulder (265) & $934 \pm 865(3)$ & \\
\hline & & R788 & Boulder (265) & $2206 \pm 1046(2)$ & \\
\hline & Alvinoconcha n. sp. & R787 & Black Forest (370) & $407 \pm 110(2)$ & \\
\hline \multirow[t]{12}{*}{ NW Eifuku } & Alvinocaris n. sp. & R791 & Mussel Mound, Champagne, Cliff House (1590) & $230 \pm 231(3)$ & \\
\hline & & R792 & Fouling $(1580)$ & $411 \pm 361(5)$ & \\
\hline & & R793 & Fouling (1580) & $103(1)$ & \\
\hline & Munidopsis n. sp. ${ }^{\mathrm{b}}$ & R791 & Mussel Mound, Cliff House (1590) & $34 \pm 25(7)$ & \\
\hline & & R792 & Fouling (1580) & $35 \pm 28(5)$ & \\
\hline & Bathymodiolus brevior & R791 & Mussel Mound, Cliff House (1590) & & $70.5 \pm 29.1(5)$ \\
\hline & & & Top Tower (1590) & $22 \pm 13(3)^{\mathrm{c}}$ & \\
\hline & & R792 & Fouling (1580) & $124 \pm 104(3)$ & $88.0 \pm 14.5(4)$ \\
\hline & & R793 & Fouling (1580) & & $87.1(1)$ \\
\hline & Shinkailepas n. sp. & R791 & Champagne (1610) & $149(1)$ & \\
\hline & & R793 & Champagne (1610) & $567 \pm 455(8)$ & \\
\hline & cf. Levensteiniella sp. & R793 & Fouling, Champagne $(1580,1610)$ & $12 \pm 6(2)$ & \\
\hline
\end{tabular}

patches of 10 to 20 mussels perched on pillow lavas, where Alvinocaris n. sp. and the scaleworm cf. Levensteiniella sp. were also present in low abundance (Table 2). The mussel beds were littered with galatheid crabs Munidopsis n. sp. (Table 2). A plume of high-temperature, high-sulphide vent fluid sustained local and dense assemblages of the limpet Shinkailepas n. sp. (Table 2). Other collected taxa included a dorvilleid and a second polynoid polychaete, and a lepetodrilid, a clypeosectid and 2 provannid gastropods (V. Tunnicliffe pers. comm.).

Similarly patchy and sparse macro-epifaunal vent assemblages were observed on the 3 sampled volcanoes on the Kermadec-S. Tonga Arc. On Monowai, assemblages of vent species occurred at a few, spatially restricted locations $\left(10 \mathrm{~s}\right.$ of $\left.\mathrm{m}^{2}\right)$ on 'Mussel Ridge', where large mounds of the mussel Bathymodiolus sp. were growing on small rocks or clumped directly on the muddy substrate (Table 3). The predatory crab Paralomis hirtella was abundant among the mussels (Table 3). Small patches of the tubeworm Lamellibrachia sp. were present at 2 locations $\sim 160 \mathrm{~m}$ apart (see Short \& Metaxas 2011). Other recorded taxa included zoarcid fish and a provannid gastropod.

On Volcano 19, the vent biological assemblages were neither particularly abundant nor extensive. Near 'Marker 40', a bed (10s of $\mathrm{m}^{2}$ ) of the clam Bathyaustriella thionipta and associated sea stars (Rumbleaster eructans) were located in a 10 -cm thick sedimented layer with a temperature of $11.1^{\circ} \mathrm{C}$ (Table 3). The flatfish Symphurus sp. was also present, although its abundance was not recorded (Tunnicliffe et al. 2010), and a few alvinellid polychaetes were present near one small venting orifice. A bythograeid crab (Austinograea sp.) was present near the base of 
Table 3. Abundance (density or percentage cover) of macrofaunal assemblages at hydrothermal vents on 3 volcanic seamounts at the Kermadec-S. Tonga Arc, measured from frame grabs obtained with a video camera attached to the ROV 'ROPOS' in May 2007 . Data are mean $\pm \mathrm{SD}$

\begin{tabular}{|c|c|c|c|c|c|}
\hline Seamount & Species & Dive & Location (depth, m) & $\begin{array}{l}\text { Density, ind. } \mathrm{m}^{-2} \\
\text { (sample size) }\end{array}$ & $\begin{array}{l}\text { Percentage cover, } \\
\% \text { (sample size) }\end{array}$ \\
\hline \multirow[t]{3}{*}{ Monowai } & Paralomis hirtella & R1043 & Mussel Ridge (1020-1060) & $7 \pm 3(5)$ & \\
\hline & Bathymodiolus sp. & R1043 & Mussel Ridge (1020-1060) & & $70.6 \pm 29.4(7)$ \\
\hline & & R1044 & Mussel Ridge (1020-1060) & & $93.9 \pm 5.3(3)$ \\
\hline \multirow{2}{*}{ Volcano 19} & Rumbleaster eructans & R1047 & Marker 40 (560) & $14 \pm 8(4)$ & \\
\hline & Austinograea sp..$^{\mathrm{a}}$ & R1048 & Big Fella (390) & $78(1)$ & \\
\hline \multirow[t]{5}{*}{ Volcano 1} & Bathymodiolus sp. & R1050 & Bubbles (200) & & $52.4 \pm 34.3(8)$ \\
\hline & & R1051 & Bubbles (200) & & $87.3 \pm 7.9(3)$ \\
\hline & & R1053 & Barracuda (100) & & $18.7 \pm 5.5(4)$ \\
\hline & & R1053 & Barracuda (100) & $2853(1)^{\mathrm{b}}$ & \\
\hline & & & & $1425 \pm 438(2)^{\mathrm{c}}$ & \\
\hline
\end{tabular}

the high-temperature chimney 'Big Fella', likely feeding on the dense microbial mat present there (Table 3).

On Volcano 1, beds (spatial extent: 100s of $\mathrm{m}^{2}$ ) of the mussel Bathymodiolus sp. were present at 2 sites (Table 3). The limpet Shinkailepas sp. was abundant both on rock and on mussel shells (Table 3), and flatfish were abundant among the mussels (Tunnicliffe et al. 2010). An unidentified lepetodrilid gastropod and the crab Xenograpsus ngatama were also recorded (Comeault et al. 2010).

\section{DISCUSSION}

Larval abundance above most volcanoes on the seamounts in the present study was generally lower (10s to $100 \mathrm{~s}$ of individuals $1000 \mathrm{~m}^{-3}$ ) than those recorded from vents on mid-ocean ridges, but similar to those measured over 2 yr at Axial Seamount in the NE Pacific (Metaxas 2004). At Endeavour Ridge and East Pacific Rise, larval concentrations were 1 to 2 orders of magnitude greater than measured here, at 100 s to 1000 s of individuals $1000 \mathrm{~m}^{-3}$ (Metaxas 2004, Mullineaux et al. 2005). Volcano 1 was the exception in the present study, where larval abundance was greater than on the other volcanoes and similar to that recorded at mid-ocean ridges. Additionally, larval abundance on non-volcanic seamounts, such as the Fieberling Guyot in the eastern Pacific, was in the order of 100s of individuals $1000 \mathrm{~m}^{-3}$ (Mullineaux \& Mills 1997), and slightly higher than measured for vent larvae on volcanically active seamounts. It is possible that I underestimated larval abundance for vent organisms by sampling on a single occasion at each seamount; however, the similarity of the observed patterns on several seamounts on 2 separate arcs, and on Axial Seamount in the NE Pacific, supports the generality of the patterns. More extensive sampling on seamounts will allow better quantification of the sources of variability in larval abundance on these poorly studied habitats.

The low larval abundance and the differences in taxonomic composition among seamounts likely reflect a combination of small spatial extent of the adult assemblages, i.e. the source populations, and the relative instability of the environment. The local source populations of adults were spatially restricted to $10 \mathrm{~s}$ of $\mathrm{m}^{2}$ to $100 \mathrm{~s}$ of $\mathrm{m}^{2}$, forming sparse patches of high population density at a particular seamount. The observed distributional characteristics within a seamount can result from gregarious settlement (Kelly et al. 2007, Short \& Metaxas 2011), patchiness in habitat suitable for settlement and colonization in terms of 
the chemical composition of the hydrothermal fluids (Kelly et al. 2007), and/or a paucity of autochthonous larval supply resulting in recruitment limitation. In contrast to the other seamounts, the lush adult assemblages on NW Eifuku and Volcano 1 may have provided larger source populations that resulted in larger and more diverse larval assemblages there. On most volcanoes, expansive areas covered in thick microbial mat were present, indicating the paucity of potential grazers (e.g. gastropods) in these locations. Ongoing eruptions, such as on NW Rota 1 and Monowai, or changing hydrothermal activity, as evidenced in 'Black Forest' on East Diamante, cause habitat instability that would further prohibit recruitment and the establishment of expansive and stable adult populations. The large differences in the dominant taxa of the adult assemblages among seamounts suggest that colonization from neighbouring seamounts within the same arc was not occurring. Rather, initial colonization by a particular taxon was likely from afar and during times with different larval availabilities. While the reproductive timing is not known for the vent species recorded on these seamounts, seasonality in reproduction has not been recorded in vent organisms, presumably because of the continuous availability of food in these habitats. Consequently, it is unlikely that the observed patterns were a consequence of the sampling timing relative to the reproductive cycle.

Larval abundance also varied with height above the vent fields. Gastropods, in particular, were more abundant near the seafloor (i.e. a few metres above the vent fields) than 20-35 m higher. All other taxa, except decapods, showed a similar trend, although it was not always statistically significant, likely because of low replication and consequent low statistical power. Greater larval abundance near the seafloor than at heights $>25$ mab has also been recorded in studies on mid-ocean ridges, such as the Juan de Fuca Ridge (Mullineaux et al. 1995, Kim \& Mullineaux 1998) and the East Pacific Rise (Mullineaux et al. 2005). Enhanced larval abundance near the seafloor may be indicative of a behavioural response by larvae, perhaps using the vent fluid or adults as a cue. Alternatively, circulation characteristics may enhance particle concentration near the ocean floor. In an uninterrupted topography of an axial valley within a mid-ocean ridge where the main flow is along the axis, increased larval abundance near the seafloor can result in a continuous and homogeneous larval supply across different vent fields along the axis (Metaxas 2004). In contrast, this pattern in abundance may limit dispersal potential across vent fields on spatially separated and topographically distinct volcanic seamounts with retentive circulation patterns.

The role of topographically rectified circulation in larval retention and in the isolation of biological communities on seamounts remains equivocal (e.g. Mullineaux \& Mills 1997, Brewin et al. 2009). The presence of recirculating retention cells, such as Taylor columns, has been suggested to result in limited dispersal of larval fishes (Dower \& Perry 2001) and benthic invertebrates (Mullineaux \& Mills 1997, Smith et al. 2004). However, the persistent occurrence of such circulation features over seamounts may not be particularly frequent, and the hypothesis of the isolation of seamounts as 'submarine islands' may not be broadly applicable (Rowden et al. 2010). In the absence of a physical mechanism, larval behaviour and life-history characteristics that affect dispersal (such as mode of development and planktonic duration) may be ultimately responsible for larval retention, and consequent genetic differentiation, on seamounts (Leal \& Bouchet 1991, Parker \& Tunnicliffe 1994, Samadi et al. 2006). Increased understanding of processes occurring during these early life-history stages is sorely needed (Clark et al. 2010, Schlacher et al. 2010).

My experimental results are indicative of a potential larval behaviour that would enhance larval abundance of limpets near the seafloor, and possibly their local retention. Soon (immediately to a few days) after release from their egg capsules, veligers were found near the bottom of the experimental containers and remained there for the duration of the experiment. In these experiments, the containers were small and conditions were not representative of the natural larval environment. Additionally, the larvae were not fed, and it is unknown whether they are lecithotrophic or could have obtained any nutrition from the rearing seawater, which was collected from the adult habitat, possibly containing a microbial food source. However, the consistency between the 2 experiments (using slightly different containers) and among batches of larvae for 1 of the species, and the difference in temporal patterns between the 2 species, support the general pattern that larvae tend to remain near the bottom in the absence of any cues. Additionally, similar to the patterns I observed for gastropods, the released nauplii of the stalked barnacle Leucolepas longa from a volcanic seamount in Papua New Guinea did not show phototaxis, $3 \mathrm{~d}$ after hatching they were swimming near the bottom of the experimental containers, and they became negatively buoyant within $6 \mathrm{~d}$ (Tunnicliffe \& Southward 
2004). As further evidence in situ, at East Diamante, gastropod veligers and protoconchs were extremely abundant (100s to 1000 s of individuals) in a suction sample collected from the seafloor and at the same location as the dacite rock that held the egg capsules. The combination of the large densities of egg capsules in certain locations ( 20 to 30 capsules $\mathrm{cm}^{-2}$ ) and the larval behaviour observed after hatching suggest a mechanism for the dense, but localized, populations of limpets. Such a behaviour, however, would retard the expansion of these populations onto other locations on the seamount, or other seamounts, even if physicochemical conditions were suitable. For example, the non-vent gastropod Nassaria problematica showed population genetic structure among seamounts on the Norfolk Ridge (New Caledonia), which was attributed to low dispersal linked with its non-planktotrophic, short larval development (Samadi et al. 2006).

The abundance of holoplankton did not vary among volcanoes on the Mariana Arc, but tended to be lower on Volcano 19 than on the other 2 volcanoes on the Kermadec-S. Tonga Arc. This is not surprising, given that all sampled taxonomic groups are cosmopolitan (even though particular species may not be) and ubiquitous in the world's oceans. Interestingly, most groups were more abundant near the seafloor than 20-35 mab, and above the 'Brimstone Pit' on NW Rota. Vent copepods are generally benthic species that inhabit vents and are expected to be found there in relatively high abundance. Other taxa are likely aggregating near the seafloor above the vents because of increased particle concentration associated with the vent fluids. Mullineaux et al. (1995) and Burd et al. (1992) found enhanced zooplankton concentrations inside or immediately above the vent plume, which they attributed to increased food availability.

In summary, the established chemosynthetic communities on most sampled volcanic seamounts were spatially restricted, forming sparse patches, included a few faunal components and had highly variable compositions within and among neighbouring seamounts. Compared to previously studied vents on mid-ocean ridges, larval abundance was relatively low in the water column above the seamounts with spatially restricted adult populations; however, it was as high as on mid-ocean ridges on the 2 seamounts with lush adult assemblages, which likely provide a larger local larval source. Additionally, limpets, which are the numerically dominant larval taxon and most ubiquitous adult taxon on all sampled seamounts, exhibited a larval behaviour which could restrict larval dispersal distance within and among seamounts. Based on these results, the structure of chemosynthetic communities on volcanic seamounts in the western Pacific Ocean is likely regulated by recruitment through limitations in: (1) local larval sources because of the small overall size of adult populations; (2) allochthonous larval supply because of the degree of isolation relative to dispersal capabilities; and (3) suitable habitat for settlement and colonization, as a consequence of geologic disturbance and chemical instability. Further, in hydrothermal vents on seamounts, as has been done for mid-ocean ridges, studies should explore the relative importance of each of these factors in limiting recruitment to the adult population. For example, studies on genetic relatedness can evaluate the magnitude of population connectivity within and among neighbouring seamounts; and mensurative and experimental studies can quantify patterns in larval supply, settlement and recruitment and identify the role of abiotic and biotic characteristics in regulating these patterns. Studies focusing on larval supply in seamounts that provide a very different physical setting from mid-ocean ridges will greatly augment our understanding of the factors that regulate chemosynthetic assemblages on hydrothermal vents.

Acknowledgements. This research was conducted as part of the Submarine Ring of Fire 2004 (funded through US NOAA Ocean Exploration and Vents Programs) and the Marine Geoscientific Research on Input and Output on the TongaKermadec Subduction Zone (MANGO) (SO-192/2) (funded through the German Bundesministerium für Bildung und Forschung (BMBF), project 03G0192) expeditions to the Mariana Arc and Kermadec-Tonga Arc, respectively. Thanks to B. Embley and U. Schwarz-Schampera, the Chief Scientists on each of the 2 cruises, for their support and enthusiasm; as well as the crews of the RVs 'Thomas Thompson' and 'SONNE' and ROV 'ROPOS' for their efficiency and hard work. K. Juniper, S. Merle, J. Rose, A. Rowden, D. Tracey, V. Tunnicliffe and C. Stevens helped while at sea and beyond, with sample collection and storage, and taxonomic identifications. R. Scheibling provided comments on the manuscript. Canadian funding was provided through the Natural Sciences and Engineering Research Council of Canada's (NSERC) Ship Time grants, and an NSERC Discovery Grant.

\section{LITERATURE CITED}

Adams DK, Mullineaux LS (2008) Supply of gastropod larvae to hydrothermal vents reflects transport from local larval sources. Limnol Oceanogr 53:1945-1955

Boehlert GW, Genin A (1987) A review of the effects of seamounts on biological processes. In: Keating BH, Fryer P, Batiza R, Boehlert GW (eds) Seamounts, islands, and atolls. Geophys Monogr Ser 43. American Geophysical 
Union, Washington, DC, p 319-344

Brewin PE, Stocks KI, Haidvogel DB, Condit C, Gupta A (2009) Effects of oceanographic retention on decapod and gastropod community diversity on seamounts. Mar Ecol Prog Ser 383:225-237

Burd BJ, Thomson RE, Jamieson GS (1992) Composition of a deep scattering layer overlying a mid-ocean ridge hydrothermal plume. Mar Biol 113:517-526

Butterfield DA, Lilley MD, Huber JA, Baross JA, Roe KK, Embley RW, Massoth GJ (2004) Mixing, reaction, and microbial activity in the sub-seafloor revealed by temporal and spatial variation in diffuse flow vents at Axial Volcano. In: Wilcock WSD, DeLong EF, Kelley DS, Baross JA, Cary SC (eds) The subseafloor biosphere at mid-ocean. American Geophysical Union, Washington, DC, p 269-289

Clark MR, Rowden AA, Schlacher T, Williams A and others (2010) The ecology of seamounts: structure, function, and human impacts. Annu Rev Mar Sci 2:253-278

Comeault A, Stevens CJ, Juniper SK (2010) Mixed photosynthetic-chemosynthetic diets in vent obligate macroinvertebrates at shallow hydrothermal vents on Volcano 1, South Tonga Arc - evidence from stable isotope and fatty acid analyses. Cah Biol Mar 51:351-359

Desbruyères D, Segonzac M, Bright M (2006) Handbook of deep-sea hydrothermal vent fauna, 2nd edn. Denisia 18. Biologiezentrum, Linz

> Dower JF, Perry RI (2001) High abundance of larval rockfish over Cobb Seamount, and isolated seamount in the Northeast Pacific. Fish Oceanogr 10:268-274

Embley RW, Chadwick WW Jr, Clague D, Stakes D (1999) 1998 eruption of Axial Volcano: multibeam anomalies and sea-floor observations. Geophys Res Lett 26:3425-3428

Embley RW, Chadwick WW Jr, Baker ET, Butterfield DA and others (2006) Long-term eruptive activity at a submarine arc volcano. Nature 441:494-497

Embley RW, Baker ET, Butterfield DA, Chadwick WW Jr and others (2007) Exploring the Submarine Ring of Fire Mariana Arc, western Pacific. Oceanography (Wash DC) 20:68-79

> Fienberg SE (1970) The analysis of multidimensional contingency tables. Ecology 51:419-433

- Gaines S, Brown S, Roughgarden J (1985) Spatial variation in larval concentrations as a cause of spatial variation in settlement for the barnacle, Balanus glandula. Oecologia 67:267-272

> Haymon RM, Fornari DJ, Von Damm KL, LilleyMD and others (1993) Volcanic eruption of the mid-ocean ridge along the East Pacific Rise crest at 9 ${ }^{\circ} 45-52^{\prime}$ N: direct submersible observations of seafloor phenomena associated with an eruption event in April, 1991. Earth Planet Sci Lett 119:85-101

Kelly N, Metaxas A, Butterfield D (2007) Spatial and temporal patterns in colonization of deep-sea hydrothermal vent invertebrates on the Juan de Fuca Ridge, NE Pacific. Aquat Biol 1:1-16

> Kim SL, Mullineaux LS (1998) Distribution and near bottom transport of larvae and other plankton at hydrothermal vents. Deep-Sea Res II 45:423-440

> Leal JH, Bouchet P (1991) Distribution patterns and dispersal of prosobranch gastropods along a seamount chain in the Atlantic Ocean. J Mar Biol Assoc UK 71:11-25

Lupton JE, Butterfield DA, Lilley M, Evans L and others (2006) Submarine venting of liquid carbon dioxide on a Mariana Arc volcano. Geochem Geophys Geosyst 7: Q08007
Marsh AG, Mullineaux LS, Young CM, Manahan DT (2001) Larval dispersal potential of the tubeworm Riftia pachyptila at deep-sea hydrothermal vents. Nature 411:77-80

McGillicuddy DJ Jr, Lavelle JW, Thurnherr AM, Kosnyrev VK, Mullineaux LS (2010) Larval dispersion along an axially symmetric mid-ocean ridge. Deep-Sea Res I 57: 880-892

- Metaxas A (2004) Spatial and temporal patterns in larval supply at hydrothermal vents in the northeast Pacific Ocean. Limnol Oceanogr 49:1949-1956

Metaxas A, Saunders M (2009) Quantifying the 'bio-' components in biophysical models of larval transport: advances and pitfalls. Biol Bull (Woods Hole) 216:257-272

Minchinton TE, Scheibling RE (1991) The influence of larval supply and settlement on the population structure of barnacles. Ecology 72:1867-1879

Mullineaux LS, Mills SW (1997) A test of the larval retention hypothesis in seamount-generated flows. Deep-Sea Res I 44:745-770

> Mullineaux LS, Wiebe PH, Baker ET (1995) Larvae of benthic invertebrates in hydrothermal vent plumes over Juan de Fuca Ridge. Mar Biol 122:585-596

> Mullineaux LS, Mills SW, Sweetman AK, Boudreau AH, Metaxas A, Hunt HL (2005) Vertical, lateral and temporal structure in larval distributions at hydrothermal vents. Mar Ecol Prog Ser 293:1-16

Mullineaux LS, Adams DK, Mills SW, Beaulieu SE (2010) Larvae from afar colonize deep-sea hydrothermal vents after a catastrophic eruption. Proc Natl Acad Sci USA 107:7829-7834

Parker T, Tunnicliffe V (1994) Dispersal strategies of the biota on an oceanic seamount: implications for ecology and biogeography. Biol Bull (Woods Hole) 187:336-345

Rowden AA, Dower JF, Schalcher TA, Consalvey M, Clark MR (2010) Paradigms in seamount ecology: fact, fiction, future. PSZNI: Mar Ecol 31(Suppl 1):226-241

Samadi S, Bottan L, Macpherson E, De Forges BR, Boisselier MC (2006) Seamount endemism questioned by the geographic distribution and population genetic structure of marine invertebrates. Mar Biol 149:1463-1475

Saunders M, Metaxas A (2008) High recruitment of the introduced bryozoan Membranipora membranacea is associated with kelp bed defoliation in Nova Scotia, Canada. Mar Ecol Prog Ser 369:139-151

> Schlacher TA, Rowden AA, Dower JF, Consalvey M (2010) Seamount science scales undersea mountains: new research and outlook. PSZNI: Mar Ecol 31(Suppl 1):1-13

Schwarz-Schampera U, Botz R, Hannington M, Adamson R and others (2007) Marine geoscientific research on input and output in the Tonga-Kermadec Subduction Zone. Cruise Report SONNE 192/2 MANGO, Hannover

Shank TM (2010) Seamounts: deep-ocean laboratories of faunal connectivity, evolution, and endemism. Oceanography (Wash DC) 23:108-122

> Short JA, Metaxas A (2011) Gregarious settlement of tubeworms at deep-sea hydrothermal vents on the TongaKermadec Arc, South Pacific. J Mar Biol Assoc UK 91: $15-22$

Smith PJ, McVeagh SM, Won Y, Vrijenhoek RC (2004) Genetic heterogeneity among New Zealand species of hydrothermal vent mussels (Mytilidae: Bathymodiolus). Mar Biol 144:537-545

Sokal RR, Rohlf FJ (1981) Biometry, 2nd edn. WH Freeman, New York, NY

Stoffers P, Worthington TJ, Schwarz-Schampera U, Han- 
nington MD and others (2006) Submarine volcanoes and high-temperature hydrothermal venting on the Tonga Arc, southwest Pacific. Geology 34:453-456

Thomson RE, Mihály SF, Rabinovich AB, McDuff RE, Veirs SR, Stahr FR (2003) Constrained circulation at Endeavour Ridge facilitates colonization by vent larvae. Nature 424:545-549

Tunnicliffe V, Southward AJ (2004) Growth and breeding of a primitive stalked barnacle Leucolepas longa (Cirripeda: Scalpellomorpha: Eolepadidae: Neolepadinae) inhabiting a volcanic seamount off Papua New Guinea. J Mar Biol Assoc UK 84:121-132

Tunnicliffe V, Embley RW, Holden JF, Butterfield DA, Mas-

Editorial responsibility: Charles Peterson,

Morehead City, North Carolina, USA soth BJ, Juniper SK (1997) Biological colonization of new hydrothermal vents following an eruption on Juan de Fuca Ridge. Deep-Sea Res I 44:1627-1644

Tunnicliffe V, Davies KTA, Butterfield DA, Embley RW, Rose JM, Chadwick WW Jr (2009) Survival of mussels in extremely acidic waters on a submarine volcano. Nat Geosci 2:344-348

Tunnicliffe V, Koop BF, Tyler J, So S (2010) Flatfish at seamount hydrothermal vents show strong genetic divergence between volcanic arcs. PSZNI: Mar Ecol 31(Suppl 1):158-167

Van Dover C (2000) The ecology of deep-sea hydrothermal vents. Princeton University Press, Princeton, NJ

Submitted: December 30, 2010; Accepted: July 1, 2011

Proofs received from author(s): August 25, 2011 